\title{
Harmonization of Requirements for Professional Competence of Managerial Accountants and Controllers
}

\author{
Bohumil KRÁL $L^{*}-$ Libuše ŠOLJAKOVÁ**
}

\section{Preface}

Especially global crisis, but also many other features which are characteristic for the changes in business environment and growing managerial needs for a quality company management manifest itself besides others in the growing pressure to professional competence of managerial accountants/controllers as experts whose principle aim is - on the basis of general coordination and optimization of company processes - to struggle for company synergic effects in relation to external environment.

This is a reason why International Group of Controlling (IGC) - an international professional association in whose activities participate - by means of Czech Association of Financial Management - also members of Department of Management Accounting of the University of Economics, Prague - has initiated a project whose general aim is to define quality standards for the work of these experts and consequently to develop a framework for more precise specification of requirements for their education, skills and experience but also for their professional approaches, values and attitudes.

\# This paper was prepared in the framework of research plan Development of Accounting and Financial Theory and its Application in Practice from Interdisciplinary Point of View (registered number MSM 6138439903).

* Prof. Ing. Bohumil Král, CSc. - Professor and Head of department; Department of Managerial Accounting, Faculty of Finance and Accounting, University of Economics, Prague, W. Churchill Sq. 4, 13067 Prague 3, Czech Republic; <kral@vse.cz>.

** Doc. Ing. Libuše Šoljaková, Ph.D. - Senior Lecturer; Department of Managerial Accounting, Faculty of Finance and Accounting, University of Economics Prague, W. Churchill Sq. 4, 13067 Prague 3, Czech Republic; <soljakl@vse.cz>. 
General aim set up by IGC is more complicated than it could appear prima facie. Requirements for competence of broader defined profession of so called professional accountants are harmonized relatively unambiguously on the base of the International Federation of Accountants (IFAC) International Education Standards (IFAC, 2003) and in the area of education they are even specified by United Nations Conference of Trade and Development Model Accounting Curriculum (UNCTAD, 2003); however, they are instruments of harmonization which are oriented primarily to auditors as professional accountants acting in public interest. With regard to their specific role in the frame of accounting profession it is apparent that also requirements for their professional competence development will be different from experts whose principle orientation is to optimize companies' activities "from the inside".

Moreover: unlike auditors whose activities in the public interest have been the subject of legislative treatment (and afterwards also of worldwide harmonization of juridical standards), analogous legal harmonization of requirements for managerial competencies has been perceived to be not only useless but even harmful with regard to creation of barriers for the experts' free movement and monopolies' development for judgment of their quality.

Also historical development difference in the areas of managerial control and applied managerial approaches manifests itself by the fact that these experts are titled differently in various parts of the globe but they are also equipped by different level of authority and responsibility and they operate in different levels of a company hierarchy.

From this view-point there is no surprise that works on the project could not commence by an immediate discussion about quality standards; project team has decided to develop an initial general paper defined project conceptual grounds, its aim, content, structure and consensual terminology.

So called "Draft for a common statement" which represents first stage of the project solution is now the subject of discussions and comments rising by national IGC members.

The aim of this paper is to describe and evaluate its content and stress the inspirations we suggest to incorporate into it. 


\section{Common statement intention}

The intention of the common statement is to generate clear and internationally valid definitions of controlling and controller's work. These definitions serve several purposes:

- they help internationally acting companies to assign tasks, competencies and responsibilities to controllers or management accountants according to their function and role in central or decentralized units of a company;

- they sharpen the "image" of the controller and the understanding of his partnering function with managers;

- they help to devise and validate the curriculum of educative organizations and make their programs meet the needs of the companies which hire controllers; and

- they point out to prospective controllers if the institution they want to choose for their education will meet the state-of-the-art topics and teach the relevant topics in depth.

Although we support this intention continually, our suggestion is to discuss the question whether it would not be appropriate to aim the whole project not for controllers operating in companies only, or - at least in some extend - to orient it also for controllers operating in other entities. This approach supports for example the Chartered Institute of Management Accountants definition of management accounting: "Management accounting is the application the principles of accounting and financial management to create, protect, preserve and increase value as deliver that value to the stakeholders of profit and not-for-profit enterprises, both public and private." (CIMA, 2000)

\section{Preamble}

Controlling is defined in the statement as the work a manager (of every hierarchical level) performs to keep his business under control. This job includes the awareness for financial performance. The controller's job is to enable managers to execute their controlling (Král, 2010, Kaplan Atkinson, 2004).

The profession is usually called "Controller" in Continental Europe whereas in English speaking countries it is called "Management Accountant". 
Král, B. - Šoljaková, L.: Harmonization of Requirements for Professional Competence of Managerial Accountants and Controllers.

- In IMA Institute of Management Accountants and in CIMA Chartered Institute of Management Accountants: publications the term "Management Accountant" is used;

- IGC the International Group of Controlling uses the term "Controller";

- IFAC International Federation of Accountants sees management accountants as one group of "Professional Accountants in Business".

Especially for the reason to find consensus for the quality standards development statement suggests simplification in the sense that controller and management accountant are thus synonyms.

Although we support this simplification for many reasons, we suggest an adjustment of primary orientation of controlling. The first sentence stresses the importance of financial performance which is understood very narrowly (see for example IAS Framework, (IASB, 2009)) especially in connection with factors influencing profit only; we suggest to use "performance" only. This term

- Reflects better that not only financial, but also non-financial size of performance in important; and

- Is in compliance with the Chartered Institute of Management Accountants: "Performance measurement is the process of assessing the proficiency with which a reporting entity succeeds, by the economic acquisition of resources and their efficient and effective deployment, in achieving its objectives. Performance measures may be based on non-financial as well as on financial information." (CIMA, 2000)

\section{Mission}

Statement defines controlling is an intrinsic part of management. In an organization all persons with the power to make decisions (managers) are also responsible to keep their part of the organization under financial control. Financial control means a business control first of all. This includes financial stability and transparency, sound and informed decision-making, forward focus on financial success, holistic view on the business and on the ensuing financial issues. 
Consequently controllers are defined like the supporting partners for managers in business questions. They are involved when managers do not have enough time or knowledge to fulfill their controlling task (Horvath, 2002).

Controllers prepare and use instruments, methods and key figures in a manner that enables managers to take decisions and to recognize their own responsibilities for results, processes and communication. The focus is on the sustainable financial success of the organization and on the performance of its parts. Also, controllers assist all other employees when they control their results, processes and communication with the help of support-systems and appropriate tools (Horngren, 2010, Drury, 2007). The relation and division of the managers' and controllers' work is depicted (by a simplified way) in Fig. 1.

Fig. 1: Relation and division of the managers' and controllers' work

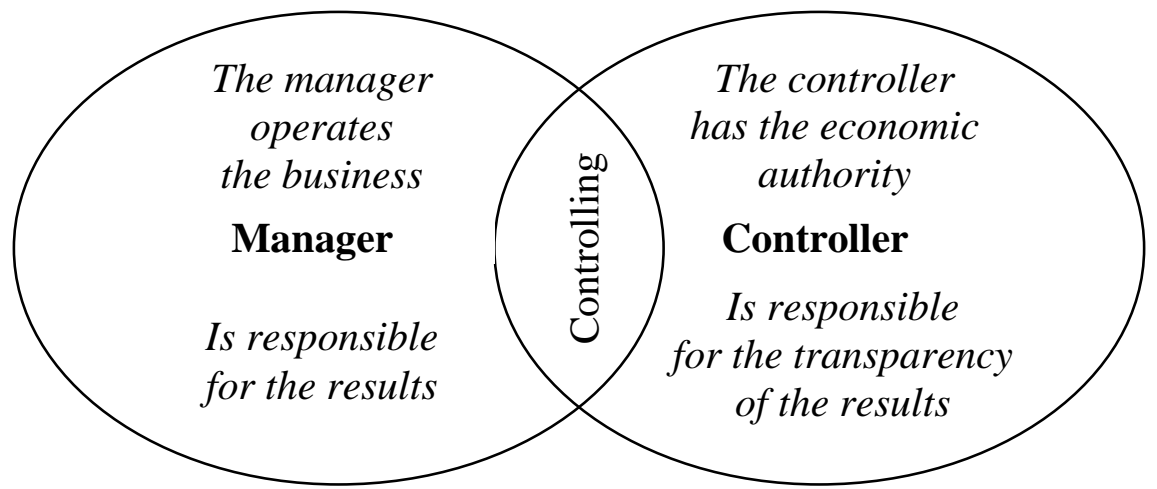

Source: IGC (2010)

Also mission contents the same narrow orientation in the first two paragraphs only. This is the reason why we suggest the adjustments which would extend the controlling understanding like a part of management oriented to not only financial but also non-financial part of business and its control.

Also third paragraph does not reflect - in our opinion - the substance of a controller added value for the company success; we suggest changing the second question in sense: "As the system of management control is too complex recently, controllers should support managers 
Král, B. - Šoljaková, L.: Harmonization of Requirements for Professional Competence of Managerial Accountants and Controllers.

especially with execution of information, but also communication, advisory and service functions of this system".

\section{Dimensions}

According to statement, it is necessary to differentiate five principle dimensions in the controllers' job: profession, function, processes, roles and job title.

\section{Profession}

Job title and function depend on the assignment of a given controller in a given organization. Therefore, profession processes and roles are the subjects of general investigation in the statement. After that, its conclusions result into multidimensional framework of controllers' activities.

Controller is a profession that involves partnering in management decision-making, devising planning and performance management systems, and providing expertise in reporting and control to assist managers in the formulation and implementation of an organization's strategies. To do so, a controller needs a qualification in accounting and finance applied to operations within all areas of organizations through a combination of leading edge techniques and an in-depth understanding of the businesses in which they operate. Specifically, a controller must be able to

- design, implement and manage (automated) integrated information systems that combine financial and non-financial data;

- collaborate in structuring transaction accounting, including all financial sub-ledger systems as well as production planning and invoicing systems;

- formulate organizational policy, strategy and objectives, producing business plans, forecasts, scorecards, cost/benefit analysis and budgeting information as appropriate;

- identify excellence in corporate governance, including qualification and management, internal due diligence and control systems, corporate social responsibility and reporting. 


\section{Processes}

The statement stresses ten principle processes which controller should master (see Fig. 2):

Fig. 2: Principle controllers' processes

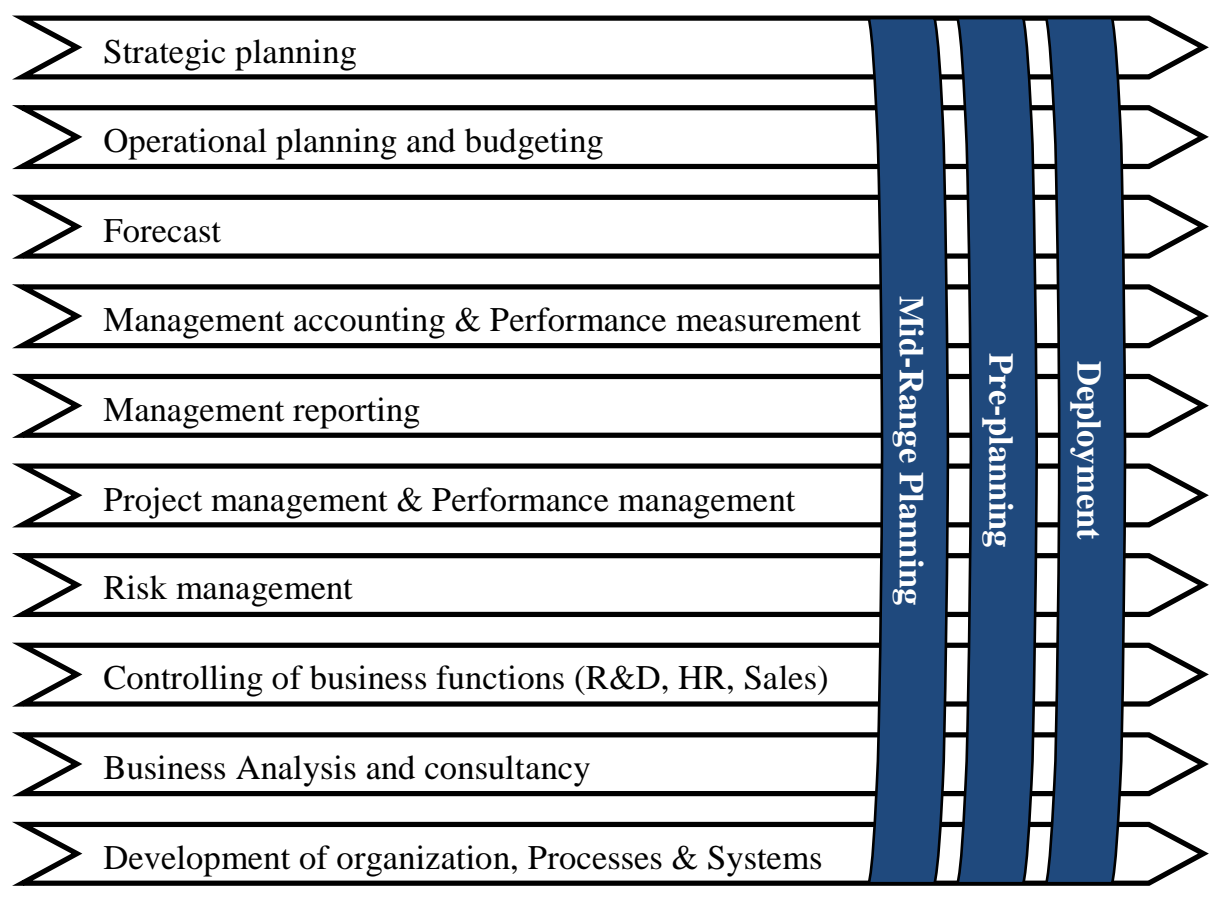

Source: IGC (2011)

\section{Roles}

Consequently, the roles of controllers can be derived from the expectations placed upon their contribution to business, both from a performance and a conformance perspective: 
Fig. 3: Controllers' Roles

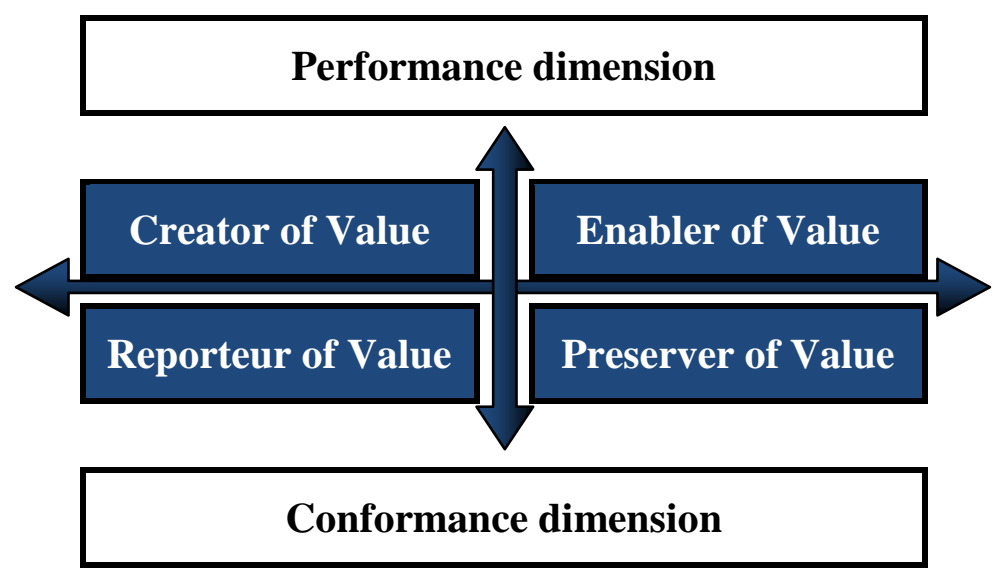

Source: The figure is based upon the IFAC $(2003,2005)$ definition "The domain of Professional Accountants in Business“"

\section{Multi-dimensional framework of controllers' activities}

To perform according to the needs of his/her customers - the managers of all hierarchical levels - the controller has to fulfill his function (x-axis). The scope of this function depends on the position of the controller. Job and sub-job (y-axis) describe the working area and the responsibilities of a given controller.

The z-axis shows the knowledge, the personal competencies and other prerequisites a controller must bring along to meet the necessities of his function and job. These elements define the contents of an educational curriculum for a controller with a defined function and job. They are therefore the basis for the development of seminars and define the scope of examination questions.

Multi-dimensional framework of controllers' activities is depicted by schematic way in Fig. 4.

In our opinion, this principle part of the Statement is very well elaborated. This is the reason we suggest the only one supplement. To be in the compliance with IFAC International Education Standards, especially with IES Framework, we suggest adjustment of z-axis into the structure Professional Education, Professional Skills, Professional Values, Ethics and Attitudes and Practical Experience Requirements. 


\section{Fig. 4: Multi-dimensional framework of controller's activities}

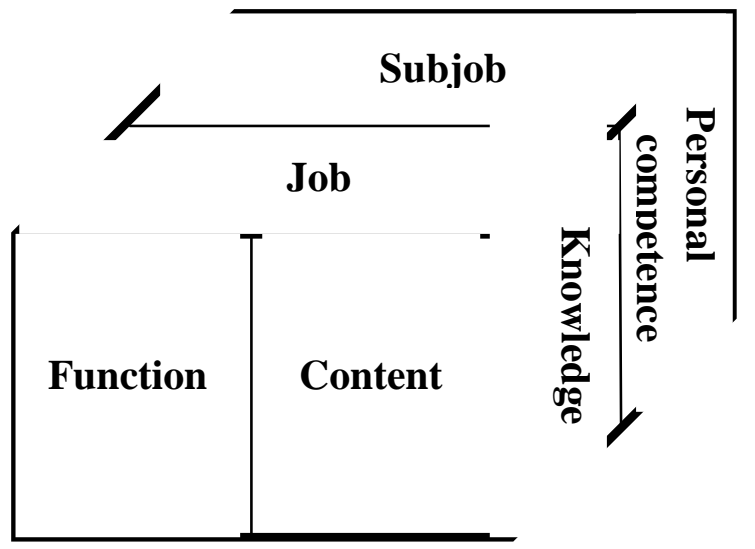

\begin{tabular}{|c|c|}
\hline \multirow{5}{*}{ Function } & Design, implement \& maintain systems \\
\hline & Enable managers \\
\hline & Coordinate \\
\hline & Deliver \\
\hline & Consult \& train \\
\hline \multirow{5}{*}{ Content } & $\begin{array}{l}\text { Management accounting integrated with enterprise resource accounting, } \\
\text { planning, reporting and forecasting }\end{array}$ \\
\hline & to fix objectives, plan, take decisions and responsibility \\
\hline & Plans \& objectives, rules, processes, incentives \\
\hline & Reports on plans, actuals, performance and forecast \\
\hline & Managers of all hierarchical levels \\
\hline \multirow{4}{*}{ Job } & Top controller \\
\hline & Head of central controller department \\
\hline & Functional controller \\
\hline & Decentral controller \\
\hline \multirow{4}{*}{ Subjob } & Responsible for all controller functions \\
\hline & $\begin{array}{l}\text { Rules \& regulations, internal consolidation, process structures, strategic } \\
\text { controller }\end{array}$ \\
\hline & $\begin{array}{l}\text { Sales \& marketing, plant, purchasing, \& working assets, capital } \\
\text { investments, participations, research \& development }\end{array}$ \\
\hline & Business unit, division, unit \\
\hline \multirow{6}{*}{ Knowledge } & Management \& financial accounting \\
\hline & Strategic planning \\
\hline & Operational planning \\
\hline & Enterprise resource accounting \& Business Intelligence \\
\hline & Management by objectives \\
\hline & Moderation techniques \\
\hline \multirow{3}{*}{$\begin{array}{c}\text { Personal } \\
\text { competence }\end{array}$} & Loyal, dependence \\
\hline & Persuasive \\
\hline & Extroverted \\
\hline
\end{tabular}

Source: IGC (2011) 
Král, B. - Šoljaková, L.: Harmonization of Requirements for Professional Competence of Managerial Accountants and Controllers.

\section{Personal requirements for a controller}

In relation to above stated framework the Statement defines also personal requirements which a controller should posses. The Statement stresses especially the following ones.

- Controllers should be the economic conscience of their organization and represent its values.

- Controllers should think and act future-oriented. To do so, they develop methods for the identification and evaluation of opportunities and risks. They also qualify the risks of the organization and help to manage them.

- Controllers should design and maintain the controlling systems and provide for a uniform data base. They work with standardized systems and instruments on recurring questions, with customized systems and instruments on specific questions.

- Controllers should be able to support and moderate the development of all performance related and value-oriented plans of the organization. They build systems to measure the capability and performance of the organization. These orient themselves both towards the conditions of the business activity as well as to the requirements of the relevant interest groups (stakeholders) in a comprehensible way. When necessary, controllers also use comparative data (benchmarks) for verification. Managers determine the content and the level of objectives in the organizational units they are responsible for.

- Controllers should prepare internal reports according to the needs of managers to run the organization with equitable valuations. If rules for external reporting contradict to the internal use and purposes, controllers prepare the data for the reconciliation between the internal and the external valuation and explain the differences in a comprehensible way.

- Controllers should be responsible to the board for the examination of the plausibility of plans and inr1stment-proposals that were prepared by others.

- Controllers should define and / or coordinate period, content, procedure and methods of the complete planning process. They compile the required comparisons between targets and actual results as well as the variances. They interpret the results, determine causes and effects and provide recommendations for 
corrective action. They devise the management information system and develop it further.

- Controllers should present and interpret the data equitable to addressees. They care that the reports correspond with the possibilities of the respective managers to influence the results. They instruct and further train the management of all levels in the use and interpretation of data.

- Controllers should work with reliable key figures and reference values (actual-/ plan-/ forecast-values). When aggregating data they consider the respective decision

- Level as well as the information needs of the receiver.

- Controller should not pass on confidential information and do not make use of it for illegal purposes or in order to damage the organization.

- Controllers should be loyal to their organization. They are openminded towards the needs of their customers, the managers. They look themselves for contact with their managers and suggest improvements and corrective actions also when not asked to do so.

In our opinion, also this part reflects by very comprehensive and understandable way controllers' personal pre-conditions. This is the reason we suggest adding the only one paragraph, corresponding with the above stated ethical size of controllers' activities: he/she should support and communicate the necessity of professional values, ethics and attitudes adherence in entity activities.

\section{Conclusions}

It is quite apparent that "Draft for a common statement" is an important, nevertheless the first step only on the road whose general aim is not only to define, but also enforce into practice and assure (more non-formal than supported by a legislation) recognition of quality standards for the managerial accountants' and controllers' work.

Nevertheless, this Draft development is - in our opinion - very beneficial. Already now, its content has been contributing to better understanding of differences which accompany this profession development in different part of globe and it enables better identification of common features, but also distinctions in profiles and professional orientations of professional accountants, auditors and professional accountants in business (as experts whose professional development is harmonized with higher level of 
Král, B. - Šoljaková, L.: Harmonization of Requirements for Professional Competence of Managerial Accountants and Controllers.

certainty recently) and of managerial accountants or controllers (whose quality professional development is the principle aim of this project).

Consequently, the Draft content creates very solid outcome for development of the first set of "Standards of good practice" and discussion materials which can inspire by examples of "best practice" which should contain

- Definition of aims, content and structure of pre-qualification education including requirement for assessment of acquired level of knowledge;

- Determination of requirements for professional skills of these experts including the ways of their acquisition;

- Definition of ways how to gain practical experiences including the manners and methods of verification whether the experiences have been really reached;

- Development of a material which would define aims, content, structure and ways of verification of continuing professional development of managerial accountants and controllers; and at last but not least

- Code of ethics development as a principle instrument of professional approaches, values and attitudes enforcement in the work of managerial accountants and controllers.

\section{References}

[1] CIMA (2000): Management Accounting. Official Terminology. London, Chartered Institute of Management Accountants, 2000.

[2] Drury J. C. (2007): Management and Cost Accounting. London, Cengage Learning, 2007.

[3] Horngren, C. - Sunden, G. et al. (2010): Introduction to Management Accounting. Englewood Cliffs, Prentice Hall, 2010.

[4] Horvath, P. (2002): Controlling. München, Verlag Franz Vahlen, 2002.

[5] IASB (2009): International Financial Reporting Standards 2007. London, International Accounting Standards Board, 2009.

[6] IFAC (2003): International Education Standards for Professional Accountants. New York, International Federation of Accountants, 2003. 
[7] IFAC (2005): The Roles and Domain of the Professional Accountant in Business. New York, International Federation of Accountants, 2003.

[8] IGC (2011): Dictionary for Controllers. Stuttgart, Schäffer-Poeschel Verlag, 2010.

[9] IGC (2010): Draft for a Common Statement (working version). St. Gallen, International Group of Controlling, 2010.

[10]Kaplan, R. S. - Atkinson, A. A. (2004): Advanced Management Accounting. Englewood Cliffs, Prentice Hall, 2004.

[11]Král, B. et al. (2010): Manažerské účetnictví. Praha, Management Press, 2010.

[12]UNCTAD (2011): Revised Model Accounting Curriculum. [on-line], Geneva, United nations Conference on trade and Development, c2003, [cit. 14 ${ }^{\text {th }}$ September, 2011], $<$ http://www.unctad.org/Templates/Download.asp?docID=4110\&intI temID $=1717 \&$ lang $=1>$. 
Král, B. - Šoljaková, L.: Harmonization of Requirements for Professional Competence of Managerial Accountants and Controllers.

\title{
Harmonization of Requirements for Professional Competence of Managerial Accountants and Controllers
}

\author{
Bohumil KRÁL - Libuše ŠOLJAKOVÁ
}

\begin{abstract}
The aim of the paper is to comment continuing works on the project whose purpose is to state generally accepted requirements for professional competence of managerial accountants and controllers. In this regard, Draft for a common Statement which defines conceptual outcomes of the project is the subject of comments.

Paper concludes that - despite the fact that Draft is the first step only - it brings substantial contributions: it has been leading to better understanding of differences which accompany this profession development in different part of globe and it enables better identification of common features, but also distinctions in profiles and professional orientations of professional accountants, auditors and professional accountants in business and of managerial accountants or controllers whose quality professional development is the principle aim of this project.
\end{abstract}

Key words: Professional Accountant; Managerial Accountant; Quality Standards; Controller; Professional Competence.

JEL classification: M41. 